\title{
Is Low-Back Pain Prevalent among Kuwaiti Children and Adolescents?
}

\author{
A Governorate-Based Study \\ Dia Shehab Khaled Al-Jarallah Fatima Al-Ghareeb Shamel Sanaseeri \\ Mariam Al-Fadhli Seham Habeeb
}

Department of Medicine, Faculty of Medicine, Kuwait University, Kuwait

\section{Key Words}

Low-back pain - Children · Adolescents

\begin{abstract}
Objective: To measure the magnitude of the problem of low-back pain among 10- to 18-year-old Kuwaiti schoolchildren in Hawalli Governorate. Subjects and Methods: A cross-sectional multistage stratified random sample of 400 schoolchildren (199 males and 201 females) of ages 10-18 years were selected from two junior and two high schools in Hawalli Governorate, Kuwait. Data on age, gender and characteristics of low-back pain such as duration, location and frequency were collected through personal interviews using a questionnaire. Low-back pain was defined as pain in the back from the 12th rib to the buttock area. Results: According to our definition, reported lifetime prevalence of low-back pain was found to be $57.8 \%(50.8 \%$ in male and $64.7 \%$ in female students), while the point prevalence was $35 \%(20.6 \%$ in male and $39.3 \%$ in female students). More female students reported low-back pain than male students, and the prevalence of low-back pain was found to increase with age in both sexes. The age of onset of low-back pain was 14 years in males and 13 years in females. The majority of students $(92.1 \%$ in males, $84.6 \%$ in females) reported pain in the low back. Almost $46 \%$ of students
\end{abstract}

\section{KARGER}

Fax +41613061234

E-Mail karger@karger.ch

www. karger.com
(C) 2004 S. Karger AG, Basel

1011-7571/04/0133-0142\$21.00/0

Accessible online at:

www. karger.com/mpp related their low-back pain to accidents. A significantly higher proportion of male students $(58.4 \%$, compared to females $36.2 \%$ ) reported low-back pain caused by accident or with duration of recovery less than a week $(21.8 \%$ for males as compared to $16.2 \%$ for female students). Female students reported more recurrent or continual low-back pain. Conclusion: Low-back pain is common among Kuwaiti students in Hawalli Governorate. Prevalence of low-back pain increased with age in both sexes. Female students reported more frequent low-back pain than male students.

Copyright $@ 2004$ S. Karger AG, Basel

\section{Introduction}

Low-back pain in adolescents is perceived to be uncommon in the clinic setting. Nevertheless, a study has suggested that it is a common symptom in this age group [1]. Little data are available regarding the complaint of low-back pain in children, probably because the disorder in this age group was initially thought to be rare. When attention was focused on low-back pain in children and adolescents it was found to be common. Studies have reported different prevalence rates of low-back pain in schoolchildren depending on the definition of low-back pain and the methods used. Olsen et al. [2] found low- 
back pain in $30.4 \%$ of American schoolchildren while Balague et al. [3] reported its presence in $27 \%$ of Swiss schoolchildren. Fairbanks et al. [4] found a prevalence of 26\% in English schoolchildren. Other studies have reported rates between 10 and 40\% [5-9]. Differences in prevalence rates reported may be attributed to variation in age, methodology, definition of low-back pain and whether lifetime prevalence or point prevalence was used in the study. In studies with subject populations of 300 children or more, the lifetime prevalence of low-back pain varied between 30 and $50 \%[2,8,10,11]$ and the point prevalence ranged from 12 to $33 \%$. The study of low-back pain in students is important since both longitudinal and cross-sectional studies performed on children and adolescents confirm the beginning of low-back pain at this stage and there is a positive correlation between history of lowback pain during adolescence and lumbar pain at adulthood [6, 12-15].

Studies have reported different prevalence rates of low-back pain according to gender. Balague et al. $[3,5]$ reported higher prevalence of low-back pain among girls than boys. However, other authors $[2,4,16]$ demonstrated no gender difference in prevalence of low-back pain. Most cross-sectional studies, the majority from $\mathrm{Eu}-$ rope and United States, reported that girls have higher prevalence of low-back pain than boys $[3,6,8,9,17,18]$. To our knowledge, no epidemiological data on this condition in schoolchildren and adolescents has been reported from the Middle East. This stimulated us to look into the low-back pain in children and adolescents in Kuwait.

The aim of this study was to measure the magnitude of the problem of low-back pain among 10- to 18-year-old Kuwaiti children in Hawalli Governorate, Kuwait, according to age and gender, and in addition, to determine its characteristics, duration, location and frequency. Lowback pain was defined in the study as pain in the back from the 12th rib to the lumbar or lumbosacral area and below-buttock area as a referred pain to the legs, thigh or feet.

\section{Subjects and Methods}

The sample included 400 schoolchildren aged 10-18 years, attending the fifth to twelfth school grades. The sampling method used was multistage stratified random sampling. The first stage included selection of the governorate using random table. Schools within the selected governorate, Hawalli, were stratified by gender into male and female schools, and the level of education as intermediate and high schools. In the second stage, two intermediate and two high schools were selected. In the third stage, classes were randomly selected equally from each level. A total of 400 schoolchildren were included, 199 male and 201 female students. The survey was conducted during March-April 2000. After obtaining students' verbal informed consent to participate in the study, data were obtained by the researchers using an Arabic questionnaire through an interview. Researchers were uniformly trained to conduct the interviews with students using the questionnaire. This was to ensure that interviewers would not lead the students to particular answers and to improve inter-rater reliability. The questionnaire was pre-tested through administration in a number of students. Subjects were able to comprehend and interpret the items given in the questionnaire correctly. Data on age, gender and characteristics of low-back pain were collected. Location of back pain determined by use of a diagram (manikin), frequency of low-back pain, history of injury or accident, duration of low-back pain, and interference of low-back pain with daily activities (school or leisure time) were studied. The rating of pain intensity was based on a visual analogue scale from 0 (no pain) to 10 (maximum pain).

Data were processed using the Statistical Package for Social Science (SPSS) software. The cut-off level for statistical significance was set as $p \leq 0.05$. Pearson chi-square test was used to assess the extent of association between two qualitative variables such as gender and different characteristics of low-back pain. Fisher's exact test replaced Pearson chi-square in $2 \times 2$ table in case the expected frequency in any of the four cells was less than 5 . The Z-normal test was used to compare between two proportions. When the assumptions of normality of compared variables were violated, the mean and standard deviation were replaced by the median and 2.5th and 97.5th percentiles as measures of location and variation and the MannWhitney U non-parametric test was used to assess the significance of the difference between two quantitative variables instead of the Student's $t$ test.

\section{Results}

\section{Prevalence of Low-Back Pain}

There was a high lifetime prevalence of low-back pain among Kuwaiti children and adolescents in Hawalli Governorate, as 231 students (57.8\%) reported having suffered from low-back pain at some time in their lives (50.8\% in male and $64.7 \%$ in female students). More female students reported low-back pain than male students. The prevalence of low-back pain was found to increase by age (table 1). Overall, there was a significant trend towards increase in the proportion of children with low-back pain as age increased, despite of inconsistencies at some ages $\left(\chi^{2}\right.$ for linear trend $\left.=24.5, p<0.001\right)$. Almost $40 \%$ of the children reported that low-back pain had interfered with their school or leisure time during the past 12 months. Female students were affected more often than male students $(46.2$ and $33.6 \%$, respectively, $\mathrm{p}<0.05$ ) and $35 \%$ of children reported point 'current' low-back pain $(20.6 \%$ in males and $39.3 \%$ in females). 
Table 1. Lifetime low-back pain (LBP) among 10- to 18-year-old Kuwaiti children according to age and gender

\begin{tabular}{|c|c|c|c|c|c|c|c|c|c|}
\hline \multirow{2}{*}{$\begin{array}{l}\text { Age } \\
\text { years }\end{array}$} & \multicolumn{3}{|c|}{ Males } & \multicolumn{3}{|c|}{ Females } & \multicolumn{3}{|c|}{ Total } \\
\hline & $\mathrm{n}$ & LBP & $\%$ & $\mathrm{n}$ & LBP & $\%$ & $\mathrm{n}$ & LBP & $\%$ \\
\hline 10 & 6 & 1 & 16.6 & 13 & 5 & 38.5 & 19 & 6 & 31.6 \\
\hline 11 & 22 & 4 & 18.2 & 28 & 14 & 50.0 & 50 & 18 & 36.0 \\
\hline 12 & 25 & 11 & 44.0 & 23 & 18 & 78.0 & 48 & 29 & 60.4 \\
\hline 13 & 22 & 10 & 45.4 & 21 & 10 & 47.6 & 43 & 20 & 46.5 \\
\hline 14 & 22 & 11 & 50.0 & 15 & 8 & 53.3 & 37 & 19 & 51.4 \\
\hline 15 & 24 & 11 & 45.8 & 26 & 18 & 69.2 & 50 & 29 & 58.0 \\
\hline 16 & 27 & 19 & 70.4 & 24 & 17 & 70.8 & 51 & 36 & 70.6 \\
\hline 17 & 26 & 17 & 65.4 & 26 & 20 & 77.0 & 52 & 37 & 71.2 \\
\hline 18 & 25 & 17 & 68.0 & 25 & 20 & 80.0 & 50 & 37 & 74.0 \\
\hline Overall & 199 & 101 & 50.8 & 201 & 130 & 64.7 & 400 & 231 & 57.8 \\
\hline
\end{tabular}

\section{Characteristics of Low-Back Pain}

Of the 231 students who had low-back pain, 106 (45.9\%) related it to accidents. Males reported a significantly higher rate of low-back pain due to accidents $(58.4 \%)$ than females $(36.2 \%), \mathrm{p}<0.001$. Male students reported higher acute low-back pain with duration for recovery from low-back pain in less than a week $(21.8 \%)$ compared to females $(16.2 \%), \mathrm{p}<0.05$. Females reported more recurrent or continual low-back pain than males. Low-back pain interfered with daily activities, varied significantly from one activity to another for those who reported recurrent or continual low-back pain. However, there was no significant difference between male and female students with respect to their need for medical advice (table 2).

\section{Location and Frequency of Low-Back Pain}

The majority of students (92.1\% in males and $84.6 \%$ in females) reported pain localized in the low-back region, compared to referred pain below buttock area and radiating pain to lower limbs. In this study, 3.5\% reported 'monthly' back pain, $10.8 \%$ once a week, $34.6 \%$ more than once a week and $26.8 \%$ daily low-back pain with a significant difference between male and female students. The median age at onset of low-back pain was 14 years in males and 13 years in females. Both sexes reported equal median pain intensity scores (table 2 ).

\section{Discussion}

This study focused on the prevalence of low-back pain among 10- to 18-year-old Kuwaiti students according to gender and age in one of the largest governorates in
Kuwait, Hawalli Governorate, and the characteristics of low-back pain among these students. It is apparent that low-back pain is common, with a prevalence rate in Kuwaiti students as high as in western schoolchildren. The differences in reported prevalence rates of low-back pain depend on several factors, including the variation in age, subject and the methodology, definition of low-back pain and type of prevalence (lifetime prevalence or point prevalence) used in the study.

The lifetime prevalence of low-back pain has been reported to vary between 30 and $50 \%$ [2, 8, 10, 11]. The lifetime prevalence of low-back pain in our study was on the upper bound $(57.8 \%)$. The point prevalence was also high $(35 \%)$. The reliability of students to recall low-back pain is proportional to its severity [1]. However, recall bias cannot be excluded due to the nature of the study as a cross-sectional survey. Burton et al. [19], in a 5-year prospective study, found that episodes of low-back pain were frequently forgotten by adolescents. Female students reported more low-back pain than male students during the last 12 months and that it interfered with their school or leisure time.

Studies have reported different rates of low-back pain in relation to gender. Many reported that the prevalence of low-back pain was higher among females than males [3, 6, 8, 9, 17, 18]. Newcomer and Sinaki [20] reported increased prevalence of low-back pain among males, while other studies reported almost equal frequency in both males and females $[2,4,16]$. In the present study, female students had higher prevalence of low-back pain than male students. This could be related to the menstrual cycle or to the fact that boys tend to worry less about this problem [8]. 
Table 2. Characteristics of low-back pain (LBP) among 10- to 18-year-old Kuwaiti children

\begin{tabular}{|c|c|c|c|c|c|}
\hline & \multicolumn{2}{|c|}{ Males $(n=101)$} & \multicolumn{2}{|c|}{ Females $(n=130)$} & \multirow[t]{2}{*}{$\mathrm{p}$ value } \\
\hline & $\mathrm{n}$ & $\%$ & $\mathrm{n}$ & $\%$ & \\
\hline \multicolumn{6}{|l|}{ Interference of LBP with school or } \\
\hline leisure time during the last 12 months & 34 & 33.6 & 60 & 46.2 & 0.05 \\
\hline LBP caused by accident & 59 & 58.4 & 47 & 36.2 & 0.001 \\
\hline Type and duration of LBP & & & & & 0.05 \\
\hline Less than a week & 22 & 21.8 & 21 & 16.2 & \\
\hline Less than a month & 11 & 10.9 & 5 & 3.8 & \\
\hline Recurrent pain & 60 & 59.4 & 84 & 64.6 & \\
\hline Continual pain & 8 & 7.9 & 20 & 15.4 & \\
\hline \multicolumn{6}{|l|}{ Interference of LBP with daily functions } \\
\hline Get to sleep & 20 & 19.8 & 31 & 23.8 & NS \\
\hline Getting up & 32 & 31.7 & 56 & 43.1 & NS \\
\hline Putting socks & 15 & 14.9 & 32 & 24.6 & NS \\
\hline Sitting & 29 & 28.7 & 70 & 53.8 & $<0.001$ \\
\hline Standing & 19 & 18.8 & 54 & 41.5 & $<0.001$ \\
\hline Walking & 34 & 33.7 & 56 & 43.1 & NS \\
\hline Participating in school sports & 23 & 22.8 & 63 & 48.5 & $<0.001$ \\
\hline Need for physician & 32 & 31.7 & 37 & 28.5 & NS \\
\hline Location of LBP & & & & & NS \\
\hline Low back & 93 & 92.1 & 110 & 84.6 & \\
\hline Below buttock & 8 & 7.9 & 20 & 15.4 & \\
\hline Frequency of LBP & & & & & 0.001 \\
\hline Once a month or more & 2 & 2.0 & 6 & 4.6 & \\
\hline Once a week & 8 & 7.9 & 17 & 13.1 & \\
\hline More than once a week & 23 & 22.8 & 57 & 43.8 & \\
\hline Daily & 35 & 34.7 & 27 & 20.8 & \\
\hline \multicolumn{6}{|l|}{ Median (2.5th, 97.5th percentiles) } \\
\hline Age at onset of LBP & \multicolumn{2}{|c|}{$14(8,17)$} & \multicolumn{2}{|c|}{$13(8,17)$} & $0.022^{\mathrm{a}}$ \\
\hline Pain intensity (score) & \multicolumn{2}{|c|}{$5(1,10)$} & \multicolumn{2}{|c|}{$5(1,10)$} & NS \\
\hline $\begin{array}{l}\text { NS = Not statistically significant, } \mathrm{p}>0.05 \text {. } \\
\text { a Mann-Whitney U test. }\end{array}$ & & & & & \\
\hline
\end{tabular}

Low-back pain was found to increase with increasing age. This is consistent with the results of Salminen et al. [21], who reported an increase in lifetime prevalence of lumbar pain from 23\% among children aged 6-13 years to $33 \%$ among those aged $14-18$ years. Salminen [17] showed that adolescents aged 15 years complained of pain more often than those aged 11 or 13. Olsen et al. [2] also found a linear increase in the prevalence of low-back pain with age. The prevalence among children aged 15 was twice as high as that found among children 12 years of age. Other studies reported similar results [4, 7, 22], and longitudinal studies [1,9] found that both lifetime prevalence and point prevalence increased with increasing age.

Low-Back Pain in Kuwaiti Children
In the present study, the median age at onset of lowback pain was 14 years in males and 13 years in female students. This may be attributed to earlier female puberty and its accompanying hormonal changes. This finding is in concert with the report of Salminen et al. [21], who showed that the first low-back pain often occurs at 13-14 years of age. Male students reported more frequent daily low-back pain and acute low-back pain than female students. Low-back pain in female students tended to predominate at a frequency of more than once weekly and the problem was also more chronic and recurrent than among male students. These patterns of expressions of low-back pain may be related to the fact that male students are more active, more involved in aggressive sports and reported more accidents than female students. It is 
recommended that a long-term longitudinal populationbased study be conducted in Kuwait to address aetiology, associated risk factors, and disability related to low-back pain in this age group, and to monitor carrying low-back pain from childhood to adulthood.

\section{Conclusion}

Our findings have shown that low-back pain is a common problem among Kuwaiti students in Hawalli Governorate, Kuwait. Low-back pain increased with age in both males and females. Female students reported more frequent low-back pain than male students.

\section{References}

1 Watson KD, Papageorgiou AC, Jones GT, Taylor S, Symmons DP, Silman AJ, Macfarlane GJ: Low back pain in school children: Occurrence and characteristics. Pain 2002;97:87-92.

2 Olsen TL, Anderson RL, Dearwater SR, Kriska AM, Cauley JA, Aaron DJ, La Porte RE: The epidemiology of low-back pain in an adolescent population. Am J Public Health 1992;82:606608.

3 Balague F, Dutoit G, Waldburger M: Low-back pain in school children. An epidemiological study. Scand J Rehabil Med 1988;20:175-179.

4 Fairbanks J, Pynsent PB, Poortvliet JA, Philips $\mathrm{H}$ : Influence of anthropometric factors and joint laxity in the incidence of adolescent back pain. Spine 1984;9:461-464.

5 Balague F, Skovron ML, Nordin M, Dutoit G, Pol LR, Waldburger M: Low-back pain in school children. Spine 1995;20:1265-1270.

6 Brattberg G: The incidence of back pain and headache among Swedish school children. Qual Life Res 1994;3(suppl 1):27-31.

7 Nissinen M, Heliovaara M, Seitsamo J, Alaranta H, Poussa M: Anthropometric measurements and the incidence of low-back pain in a cohort pubertal children. Spine 1994;19:13671370.

8 Salminen JJ, Pentti J, Terho P: Low-back pain and disability in 14-year old school children. Acta Paediatr 1992;81:1035-1039.
9 Troussier B, Davoine P, de Gaudemaris R, Fauconnier J, Phelip X: Back pain in school children: A study among 1,178 pupils. Scand J Rehabil Med 1994;26:143-146.

10 Kristjansdottir G: Prevalence of self-reported back pain in school children: A study of sociodemographic differences. Eur J Pediatr 1996; 155:984-986.

11 Balague F, Nordin M, Skovron ML, Dutoit G, Yee A, Waldburger M: Non-specific low-back pain among schoolchildren: A field survey with analysis of some associated factors. J Spinal Disord 1994;7:374-379.

12 Deyo RA, Tsui-Wu YJ: Descriptive epidemiology of low-back pain and its related medical care in the United States. Spine 1987;12:264268.

13 Harreby M, Neergaard K, Hesselsoe G, Kjer J: Are radiologic changes in the thoracic and lumbar spine of adolescents risk factors for lowback pain in adults? Spine 1995;20:22982302.

14 Leboeuf-Yde C, Kyvik KO: At what age does low back pain become a common problem? A study of 29,424 individuals aged 12-41 years. Spine 1998;23:228-234.
15 Leino PI, Berg MS, Paska P: Is back pain increasing: Results from international surveys in Finland during 1978/9-1992. Scand J Rheumatol 1994;23:269-276.

16 Taimela S, Kujala UM, Salminen JJ, Viljanen $\mathrm{T}$ : The prevalence of low back pain among children and adolescent. Spine 1997;22:11321136.

17 Salminen JJ: The adolescent back: A field survey of 370 Finnish school children. Acta Paediatr Scand Suppl 1984;315:1-122.

18 Viikari-Juntura E, Vuori J, Silverstein A, Kalimo R, Kuosma E, Videman T: A life-long prospective study on the role of psychosocial factors in neck, shoulder and low-back pain. Spine 1991;16:1056-1061.

19 Burton AK, Clarke RD, Mc Clune TD, Tillotson KM: The natural history of low back pain in adolescents. Spine 1996;21:2323-2328.

20 Newcomer K, Sinaki M: Low-back pain and its relationship to back strength and physical activity in children. Acta Paediatr 1996;85:14331439.

21 Salminen JJ, Erkintalo M, Laine M, Pentti J Low-back pain in the young. Spine 1995;20: 2101-2108.

22 Grimmer K, Williams M: Gender-age environmental associates of adolescent low back pain. Appl Ergon 2000;31:343-360. 